\title{
Erratum to: Gustilo-Anderson Classification
}

\author{
Paul H. Kim MD, Seth S. Leopold MD
}

Published online: 6 October 2012

(C) The Association of Bone and Joint Surgeons (R 2012

\section{Erratum to: Clin Orthop Relat Res \\ DOI 10.1007/s11999-012-2376-6}

The title of this article is incorrect as presented. The correct title is: In Brief: Gustilo-Anderson Classification.

The online version of the original article can be found under doi:10.1007/s11999-012-2376-6.

P. H. Kim, S. S. Leopold ( $\square)$

Department of Orthopaedics and Sports Medicine,

University of Washington, 1959 NE Pacific Street,

Box 356500, Seattle, WA 98195-6500, USA

e-mail: leopold@u.washington.edu; leopold@uw.edu 